\title{
Balans van 25 jaar arbeids- en organisatiepsychologie: nieuwe thema's en methoden, maar praktische relevantie onder druk
}

\author{
Peter Smulders en Roel Schouteten*
}

\begin{abstract}
Op basis van reviewartikelen, trend- en inhoudsanalyses poogt dit artikel een overzicht te geven van 25 jaar ontwikkelingen in de A\&O-psychologie. Daarbij gaat de aandacht uit naar zowel internationale als nationale ontwikkelingen. Geconcludeerd wordt dat er grote verschillen bestaan tussen de Verenigde Staten, het Verenigd Koninkrijk en een aantal continentaal-Europese landen in prioritaire onderzoeksthema's. In het Nederlandse taalgebied waren drie onderwerpen de afgelopen tien jaar het meest populair: (I) competenties, leren en employability, (2) rechtvaardige arbeidsverhoudingen, psychologische contracten en baanonzekerheid, en (3) stress, vermoeidheid en burn-out. Daarnaast waren opkomende thema's: prestaties, productiviteit en innovatief gedrag en pesten, agressie en intimidatie op de werkplek. Op deze gebieden spelen Nederlandse en Vlaamse A\&O-psychologen internationaal een vooraanstaande rol. Duidelijk verminderd is de aandacht voor thema's als medezeggenschap, werkoverleg, bedrijfsdemocratisering en organisatieverandering. Meta-analyses en meer geavanceerde analysetechnieken hebben een grote vlucht genomen. Maar zowel in Nederland als elders bestaat er een voortgaande discussie over de wens om de kloof tussen wetenschap en praktijk te dichten. Ook is er kritiek op het feit dat het werk in kleine bedrijven en dat van zelfstandigen veronachtzaamd wordt en dat representatief steekproefonderzoek te weinig aandacht krijgt. Het artikel eindigt met een aantal - op maatschappelijke vraagstukken inspelende - onderzoekswensen voor de toekomst.
\end{abstract}

Trefwoorden: A\&O-psychologie, inhoudsanalyse, ontwikkelingen, publicatietrends

\section{Inleiding}

De laatste decennia werd de wereld van het werk gekenmerkt door demografische veranderingen als ontgroening, vergrijzing en diversifiëring, technologische veranderingen met telewerken en werken in virtuele kantoren en teams, economische veranderingen met de groei van de dienstensectoren en de inkrimping van de traditionele sectoren als industrie en landbouw, en dus het verminderen van een aantal arbeidsrisico's. Uitbesteding van werk en flexibilisering van functies en werktijden zijn grotendeels eveneens economisch gestuurd. Ten slotte zagen we culturele veranderingen, zoals individualisering, een verdere voortschrijding van de vrouwenemancipatie, het streven naar gelijke beloning, participatief management enzovoort. Hoe heeft de arbeids- en organisatiepsychologie (A\&O-psychologie) daarop ingespeeld?

In dit artikel zal eerst de organisatie van het vakgebied op hoofdlijnen worden beschreven. Ook de raakvlakken met aanverwante vakgebieden komen daarbij aan de orde. Vervolgens zullen aan de hand van enkele recente overzichtsartikelen en eigen analyses van publicatietrends de wetenschappelijke ontwikkelingen van de afgelopen 25 jaar

* Peter Smulders is verbonden aan TNO Kwaliteit van Leven, divisie Arbeid te Hoofddorp; Roel Schouteten is werkzaam bij de Radboud Universiteit Nijmegen, Faculteit Management Wetenschappen. E-mailadres: peter.smulders@tno.nl. 
worden geschilderd. Ten slotte zullen inzake een aantal centrale thema's de verworvenheden en lacunes meer in detail worden beschreven. Het artikel wordt afgesloten met conclusies en onderzoekswensen voor de toekomst.

\section{Het vakgebied van arbeid \& organisatie-psychologen}

In de Engelstalige literatuur is Industrial and Organizational Psychology (I\&O-psychologie) min of meer het equivalent van A\&O-psychologie. Deze termen gebruiken we hier door elkaar. Een uitgangspunt in de I\&O-psychologie is de Fit-gedachte: zowel het individu als de organisatie is er het meest mee gebaat als de fit tussen beide goed is. Om dat te bereiken is selectie, training en ontwikkeling van personeel van belang, maar ook ontwerp, ontwikkeling en verandering van organisaties.

Zoals een van de grootheden in dit vakgebied, Lyman Porter, kortgeleden (2008) schetste, is het vak ontstaan vanuit de industriële psychologie. In de eerste helft van de vorige eeuw waren Amerikaanse psychologen binnen de American Psychological Association (APA, thans 150.000 leden) verenigd in de Division of Industrial Psychology. Pas in 1973 ontstond de Division of Industrial and Organizational Psychology, ook wel de Society for Industrial and Organizational Psychology (SIOP) genaamd. Uiteraard bestaan er in de Verenigde Staten en elders aanpalende, grotendeels overlappende vakgebieden als Organizational Behavior en Human Resource Management (HRM). De Academy of Management - de belangrijkste beroepsvereniging van organisatieonderzoekers naast de APA - kent een groot aantal divisies en interessegroepen en staat open voor wetenschappers, maar ook voor wetenschappelijk geïnteresseerde praktijkmensen. De Academy heeft ruim 18.000 leden uit meer dan honderd landen en geeft een viertal wetenschappelijke tijdschriften uit.

In Nederland wordt al lang niet meer gesproken van I\&O-psychologie, maar van A\&Opsychologie. Het bekende handboek van Drenth et al. uit 1984, heden ten dage dus 25 jaar oud, had als titel Handboek arbeid \& organisatie psychologie. Het Nederlands Instituut voor Psychologen (NIP), de beroepsvereniging van Nederlandse psychologen met 13.000 leden, heeft ook een sector Arbeid \& Organisatie.

Verder bestaat de Werkgemeenschap van onderzoekers in de Arbeids- \& Organisatiepsychologie (WAOP), een vereniging die arbeids- en organisatiepsychologisch onderzoek in Nederland stimuleert. Het gaat daarbij zowel om toegepast als om meer fundamenteel onderzoek. Het bevorderen van samenwerking tussen wetenschappers en professionals die op dit gebied werkzaam zijn, vormt een expliciet doel voor de WAOP. De WAOP verzamelt en distribueert informatie over de Nederlandse A\&O-psychologie, werkt onder meer samen met het NIP en is lid van de European Association of Work and Organizational Psychologists (EAWOP).

Over de samenhang van de vakgebieden psychologie, sociologie en economie is in de Verenigde Staten een interessant onderzoek uitgevoerd. Door Agarwal \& Hoetker (2007) is namelijk over de 25-jaarsperiode 1980-2005 geanalyseerd welke de bijdragen zijn geweest van de drie disciplines aan een belangrijk managementtijdschrift, het Academy of Management Journal (AMJ), een gerenommeerd platform voor diverse disciplines. De analyses vonden plaats op basis van citatiegegevens van artikelen gepubliceerd in $A M J$, die naar discipline werden gecategoriseerd. Dan blijkt dat de psychologische literatuur in $A M J$ een wat uitzonderlijke positie inneemt. Psychologisch getinte artikelen, die veel voorkomen in $A M J$, worden namelijk later wel door psychologisch getinte tijdschriften geciteerd, maar niet door economische en sociologische tijdschrif- 
ten. 'Thus, the discussion of psychological constructs in the management literature serves to inform psychology, but not other disciplines', concluderen de auteurs. De economisch getinte bijdragen aan $A M J$ bereiken wel de sociologie, maar niet de psychologie. De sociologische bijdragen aan $A M J$ worden niet significant meer of minder geciteerd door de andere twee disciplines.

Over de verhouding tussen A\&O-psychologen en HRM-onderzoekers heeft de Tilburgse hoogleraar A\&O-psychologie Karin Sanders (2006) zich kritisch uitgelaten. Ze constateert dat het gaat om twee werelden met eigen kennisoverdracht, die zich onafhankelijk van elkaar ontwikkelen en nauwelijks gebruikmaken van de expertise van de andere discipline. In haar visie heeft dat ten dele te maken met het feit dat HRM-onderzoekers relatief meer uit de bedrijfskunde komen, en dat dit vakgebied meer op casestudies leunt dan de A\&O-psychologie, terwijl in de laatste discipline vragenlijstonderzoek met gevalideerde instrumenten prevaleert. Volgens Sanders zou HRM-onderzoek wat meer 'wetenschappelijke regie' kunnen gebruiken en A\&O-onderzoek wat contextgevoeliger kunnen worden. Op dit laatste aspect komen we nog terug.

De laatste twee decennia is het vakgebied van de arbeid \& gezondheid-psychologie (A\&G-psychologie) verzelfstandigd en tot ontwikkeling gekomen. De ontstaansgeschiedenis en de toekomstperspectieven zijn onder meer geschetst door Schaufeli (2004b). Nederlandse en Vlaamse psychologen spelen op dit terrein een belangrijke rol. Zo vermelden Cox \& Tisserand (2006) bijvoorbeeld dat Nederland de vierde plaats inneemt wat betreft bijdragen aan het tijdschrift Work \& Stress, achter het Verenigd Koninkrijk, de Verenigde Staten en Australië, maar voor Zweden, Noorwegen, Duitsland en België. Schaufeli (2004a; 2004b) stelt dat Nederland een belangrijke rol kon spelen, omdat in ons land een vruchtbare juridische, politieke, maatschappelijke, psychologische en institutionele bodem aanwezig is waarop de A\&G-psychologie kan gedijen. Hij doelt hier onder andere op de invoering van de Arbowet van 1983, op de grotere acceptatie van thema's als overspannenheid en psychosociale belasting in Nederland, de mogelijk daarmee samenhangende omvang van de psychisch gerelateerde component van de arbeidsongeschiktheid en de hoge daarmee gepaard gaande kosten.

\section{Internationale ontwikkelingen in de arbeid \& organisatie-psychologie}

De I\&O- (of A\&O-)psychologie beslaat een breed terrein. Het gaat onder andere om personeelsbeoordeling, beroepskeuze, werving en selectie, motivatie en prestatiemeting, training en loopbaanontwikkeling, conflicten en conflicthantering, leiderschapsvormen, besluitvorming, communicatie, de invloed van technologische ontwikkelingen, arbeidstevredenheid, stress en burn-out, beloning, personeelsverloop en ziekteverzuim en veranderingsprocessen. Om enig zicht te krijgen op de brede ontwikkelingen in het vakgebied van de afgelopen 25 jaar hebben we ons gebaseerd op reviewartikelen, historische beschouwingen, trendanalyses en dergelijke. Daarbij konden selectieve keuzes uiteraard niet worden ontlopen. Eerst vatten we een aantal publicatietrends in de A\&O-psychologie in de internationale literatuur samen. 


\section{Publicatietrends in de A\&O-psychologie}

Om te achterhalen welke ontwikkelingen zich voorgedaan hebben in de publicatieonderwerpen, voerden Cascio en Aguinis (2008) een inhoudsanalyse uit op alle 5.780 artikelen die in een periode van 45 jaar (1963-2007) verschenen in twee vooraanstaande Amerikaanse A\&O-tijdschriften (Personnel Psychology en Journal of Applied Psychology). Deze twee tijdschriften vertoonden een opmerkelijke gelijkenis wat betreft de favoriete thema's. De aandacht bleek gedaald te zijn voor thema's als human factors, loopbaan en beroepskeuze, en motivatie. Thema's waarover het aantal publicaties op een relatief gelijk niveau bleef, waren arbeidstevredenheid en binding, leiderschap, training, leren en ontwikkeling, en ziekteverzuim en verloop. En thema's waarover in groeiende frequentie gepubliceerd werd, waren besluitvorming, organisatiecultuur, prestatiebeoordeling en -feedback, teams en werkgroepen, stress en burn-out, en arbeid en de thuissituatie.

Tharenou (2001) probeerde de publicatietrends vast te stellen op basis van gepubliceerde meta-analyses in zeven vooraanstaande A\&O-tijdschriften in de periode 1995-2000. Haar conclusie was dat er twee brede ontwikkelingen te ontdekken zijn. De eerste trend betreft de toenemende aandacht voor de voorspelling van 'employee responses', zoals prestaties, motivatie, betrokkenheid, werkstress, veilig gedrag, gezondheid, personeelsverloop en ziekteverzuim. De tweede trend betreft de toenemende aandacht voor de effecten van 'psychologische praktijken en processen', zoals motivering en leidinggeven.

Stijging en daling van het aantal publicaties worden door de auteurs ten dele gekoppeld aan maatschappelijke vraagstukken ('human capital trends'). Een conclusie van de auteurs is echter ook, dat de publicatietrends voor een belangrijk deel nauwelijks gelijke tred houden met die maatschappelijke ontwikkelingen.

\section{Stappen voorwaarts en lacunes in de A\&O-psychologie}

Recente voorbeelden van analyses van en beschouwingen over het vakgebied van de A\&O-psychologie en aanverwante terreinen zijn die van Dunnette (1998), Patterson (2001), Sparks et al. (2001), Tharenou (2001), Borman et al. (2003), Schaufeli (2004a; 2004b) en Porter (2008). Vragen die daarbij aan de orde kwamen, waren welke de constanten en welke de veranderingen zijn geweest in het vakgebied. Welke belangrijke stappen voorwaarts zijn gezet? Welke lacunes zijn te constateren? Wat zou de A\&Opsychologie moeten doen om het vakgebied nog meer te doen floreren? Op basis van de antwoorden uit deze studies schetsen we enkele theoretische, methodologische en empirische ontwikkelingen en inzichten uit de afgelopen 25 jaar. Enige algemeenheid zal hier moeten worden betracht, omdat het onmogelijk is om de diverse deelterreinen van de A\&O-psychologie apart onder de loep te nemen.

\section{Verschillen tussen landen}

Om te beginnen zij vermeld dat er binnen de A\&O-psychologie grote verschillen tussen landen bestaan in aandacht voor onderzoeksonderwerpen. Erez (1994) berekende inzake 25 thema's de aantallen artikelen die in de jaren tachtig gepubliceerd werden in organisatiepsychologische onderzoekstijdschriften naar land van auteur. In drie Angelsaksische landen (de Verenigde Staten, Canada en Groot-Brittannië) stond selectie van personeel op de eerste plaats. In die drie landen scoorden ook leiderschap en 'gender'verschillen hoog. Aan de andere kant waren onderzoeksartikelen over gezondheid en 
stress van werkenden in Europa (Scandinavische landen en Duitsland) en Japan het meest populair. In de Scandinavische landen was zelfs 53\% van de artikelen gewijd aan gezondheid en stress van werkenden. Het verschil in aandacht voor personeelsselectie versus stress en gezondheid reflecteert waarschijnlijk verschillen in maatschappelijke opvattingen tussen landen.

\section{Conjuncturele effecten op werk en gezondheid}

Vanwege de economische veranderingen in de afgelopen decennia hebben Sparks et al. (2001) een poging gedaan om de conjuncturele effecten op werk en gezondheid in kaart te brengen. Mede op basis van psychologisch onderzoek is hun conclusie dat economische gevolgen als herstructurering, inkrimping, bedrijfsverplaatsing enzovoort in de afgelopen 25 jaar voor werknemers hebben geleid tot meer baanonzekerheid, allerlei vormen van afwijkende werktijden, minder controle over het werk en de loopbaan, en het te maken krijgen met een veranderde, veeleisender leiderschapsstijl van managers, die zelf onder prestatiedruk staan. Stress, burn-out, depressies en ziekteverzuim kunnen hiervan mogelijke gevolgen zijn. Lange tijdreeksen van het CBS hebben overigens de claim van de verminderde autonomie van werknemers, althans wat Nederland betreft, tegengesproken (Smulders, 2005).

Cascio (1995), in zijn excellente artikel over de toekomst van de A\&O-psychologie in de veranderende wereld van werk, schetst de ontwikkeling naar een heel ander leiderschapstype dat in nieuwe bedrijven en kantoren nodig is, namelijk de niet-autoritaire en niet-top-down manager, met visie op de toekomst, die deze visie ook in de hele organisatie kan laten doorklinken. Dat nieuwe motiverende en enthousiasmerende managerstype heeft grote behoefte aan 'empowered workers' die zelfstandig kunnen opereren, initiatief nemen en klantgeoriënteerd zijn.

\section{Een positieve kijk op werk}

Schaufeli (2004a; 2004b) nam verleden, heden en toekomst van de psychologie van arbeid en gezondheid onder de loep. Hij komt daarbij tot de conclusie dat het traditionele $A \& G$-onderzoek zich vooral richt op negatieve toestanden en op disfunctioneren, zoals pesten op het werk, burn-out, aandoeningen, ongevallen en ziekteverzuim. Hij houdt een pleidooi voor een positieve benadering waarbij het traditionele ziektedenken wordt aangevuld met een positief gezondheidsdenken, dat aandacht heeft voor positieve emoties, zoals plezier, geluk, trots, authenticiteit, bevlogenheid, hoop, optimisme, zelfbepaling, collegialiteit, flow en weerbaarheid. Deze oproep heeft inmiddels geleid tot een Bevlogenheidvragenlijst en tot een reeks van publicaties over bevlogenheid en hoe die te bevorderen. De indruk is dat de oproep internationaal nog niet tot grote weerklank heeft geleid.

\section{Erfelijkheid en werk}

Dunnette (1998) beschrijft uitvoerig welke nieuwe inzichten er in de jaren negentig ontstaan zijn door psychologisch onderzoek - vaak met behulp van tweelingen - naar de genetische of erfelijke invloeden op zaken als intelligentie, vaardigheden, loopbaanbelangstelling, arbeidstevredenheid en geluksgevoelens. Beroepskeuze en arbeidstevredenheid zouden voor een groot deel erfelijk bepaald worden. Diverse auteurs gaan er tegenwoordig van uit dat de genetische component in deze arbeidsaangelegenheden belangrijker is dan omgevingsfactoren. 


\section{Werkgever- of werknemerperspectief}

Een door meerdere Amerikaanse auteurs geuit kritiekpunt is dat de $\mathrm{A} \& \mathrm{O}$-psychologie te vaak en te lang het perspectief van het management heeft gekozen. Uiteraard heeft dit zijn effecten gehad op de onderzoeksthema's die A\&O-psychologen kiezen. Zij zouden zich meer gelegen moeten laten liggen aan het perspectief van het welbevinden van werknemers en maatschappij als geheel. Borman et al. (2003) menen dat daar in de jaren negentig verandering in is gekomen. Zo wordt bij selectieonderzoek niet alleen meer vanuit organisatieperspectief gekeken, maar ook vanuit de visie van de werkzoekende. De wensen en belangen van werkenden zijn dus in belang toegenomen. Patterson (2001) voegt hieraan toe, dat de opkomende belangstelling van A\&O-psychologen voor de negatieve gezondheidseffecten van inkrimping en flexibilisering, voor lange werktijden en overwerk en voor baanonzekerheid ook in deze zin uitgelegd kan worden.

\section{Kloof tussen wetenschap en praktijk}

Zoals ook Cascio en Aguinis (2008) schetsten, zou de A\&O-psychologie meer werk moeten maken van het dichten van de kloof tussen wetenschap en praktijk. Dit klemt des te meer omdat ook de externe omgeving - concurrentie op wereldschaal, technologische ontwikkelingen, interacterende financiële systemen - constant verandert. Porter (2008) voegt eraan toe dat in het belendende terrein van HRM praktijkmensen een veel grotere rol spelen, bijvoorbeeld in reviewprocedures en bij het toekennen van onderzoekssubsidies. Patterson (2001) en anderen signaleren dat de sterke expansie van het aantal adviserende of praktijkpsychologen de wetenschap en de praktijk eerder uit elkaar drijft dan tot elkaar brengt, ten dele resulterend in 'irrelevante theorie' en 'ongefundeerde praktijk'.

Ondanks deze kritiek constateren Dunnette (1998) en Borman et al. (2003), dat de Amerikaanse A\&O-psychologie wel degelijk praktisch en beleidsrelevant is gebleken. Zo is er inhoudelijk in de Verenigde Staten grote vooruitgang geboekt op het gebied van het meten van werkprestaties en het voorspellen ervan op basis van technische kennis en communicatieve en leiderschapsvaardigheden. Een groot en langlopend project bij het Amerikaanse leger was hierbij behulpzaam. Een tweede praktische verworvenheid was de ontwikkeling door A\&O-psychologen van het zogenoemde Occupational Information Network ten behoeve van de Amerikaanse arbeidsmarkt en op verzoek van het US Department of Labor. Het systeem beschrijft de karakteristieken en vereisten van banen en de kenmerken en kwalificaties die een werknemer moet hebben om de baan goed te kunnen vervullen.

Te oordelen naar de onderwerpen die in het Nederlandstalige tijdschrift Gedrag \& Organisatie aan de orde komen (zie verderop in dit artikel), lijkt het erop dat Nederlandstalige A\&O-psychologen - gezien de gekozen onderzoeksthema's - wel meer inspelen op relevante maatschappelijke ontwikkelingen. De kritiek blijft natuurlijk mogelijk dat in de discussie van de resultaten te weinig aandacht zou worden besteed aan de praktische of maatschappelijke relevantie. Dit kwam althans naar voren uit een lezersonderzoek van Gedrag \& Organisatie (Schalk, 2009).

\section{Contextloos onderzoek}

Door diverse reviewers (onder andere Tharenou, 2001) is de laatste jaren geconcludeerd dat $\mathrm{A} \& \mathrm{O}-$ onderzoek de neiging heeft te veel plaats te vinden zonder de context expliciet te duiden. Johns (2006) laat zien dat relaties tussen variabelen stevig kunnen verschillen, zelfs kunnen omslaan van positief naar negatief, afhankelijk van bijvoorbeeld beroepsgroep, bedrijfstak, type dienstverband, land of regio, tijdsperiode enzovoort. Context kan ook de causale richting van een relatie beïnvloeden, zoals blijkt uit uiteen- 
lopende onderzoeksresultaten rond de relatie arbeidstevredenheid-ziekteverzuim. En bij onderzoek naar prestatiebeoordeling is het bijvoorbeeld van belang te weten binnen welk organisatie- en personeelsbeleid dat plaatsvindt, en in hoeverre vriendschapsrelaties een rol spelen bij de beoordelingsprocedures.

\section{Grotebedrijvenbias}

Een andere vorm van kritiek staat bekend als de 'grotebedrijvenbias'. Patterson (2001) is van mening dat $\mathrm{A} \& \mathrm{O}$-psychologen zich te veel gebaseerd hebben op de situatie in grote bedrijven en instellingen. Naar haar mening verstoort dit een realistische kijk op de werkelijkheid. Met name de gang van zaken bij kleine bedrijven en zelfstandigen blijft grotendeels onzichtbaar. Vele andere psychologen hebben gelijksoortige kritiek op het vakgebied, omdat het verregaande consequenties kan hebben voor de generalisatie van de onderzoeksresultaten.

\section{Opkomst van meta-analyses}

De sterke toename van meta-analyses in de A\&O-psychologie wordt als een verworvenheid van de jaren tachtig en negentig gezien (Dunnette, 1998). Alleen al in de tienjaarsperiode 1992-2001 telden Borman et al. (2003) 119 gepubliceerde meta-analyses in het vakgebied. Theorievorming en modelontwikkeling zijn tot verdere bloei gekomen dankzij de vele meta-analyses, maar ook dankzij nieuwe statistische methoden als Hierarchical Linear Modeling (HLM), Structural Equation Modeling (SEM), Dynamic Time Series Analysis, en Confirmatory Factor Analysis (CFA).

\section{Methodenkritiek}

Anderzijds wordt de A\&O-psychologie volgens Porter (2008) ook gehinderd door een aantal methodologische barrières. Het gaat hier bijvoorbeeld om het gebrek aan sterke oorzaak-gevolgstudies, een onvoldoende kritische blik op self-reports en het onvoldoende rekenschap geven van mogelijke problemen door 'common method variance'. Porter (2008) is van mening dat de laatste decennia wel vooruitgang is geboekt op dit terrein en dat verdere verbetering in het verschiet ligt.

\section{Ontwikkelingen in Nederland en Vlaanderen}

Om zicht te krijgen op de onderwerpen waar de Nederlandstalige A\&O-psychologie 25 jaar geleden accenten op legde, bekijken we de inhoudsopgave van het Handboek arbeid \& organisatie psychologie van Drenth et al. (1984). Dit handboek vervulde een centrale rol bij de opleiding van A\&O-psychologen. Het lijkt erop dat de structuur van dit handboek geïnspireerd is geweest op het gerenommeerde Amerikaanse Handbook of industrial and organizational psychology (Dunnette, 1976). Ook in Dunnettes handboek treft men hoofdstukken aan over persoonskenmerken, motivatie en satisfactie, taakkenmerken, personeelsbeoordeling, training, personeelsaanname, beroepskeuze, ergonomie, groepskenmerken, leiderschap, conflict en stress, organisatiekenmerken en -theorieën, organisatieverandering en -ontwikkeling, besluitvorming, automatisering en het crossculturele perspectief.

Zaken die bij Drenth et al. (1984) onder de loep genomen worden, maar bij Dunnette ontbreken, zijn relatief Nederlandse invalshoeken - althans toentertijd - zoals werkoverleg, werkstructurering, bedrijfsdemocratisering, sociotechniek, vrouwen en werk, en werkloosheid. Aan de andere kant zoekt men bij Drenth et al. tevergeefs naar een 
gevoelig thema als het management van inefficiënt gedrag. In een latere versie van het handboek is wel een hoofdstuk over ziekteverzuim opgenomen.

Maar van groter belang voor dit artikel is wat er in de 25 jaar na de publicatie van het handboek van Drenth et al. is veranderd in de aandacht voor de diverse thema's.

Daartoe is een inhoudsanalyse gemaakt van de laatste tien jaargangen van het Nederlandse A\&O-tijdschrift Gedrag \& Organisatie. Aan dit tijdschrift dragen zowel Nederlandse als Vlaamse auteurs bij. Aan elk van de circa 280 artikelen in de laatste tien jaargangen is, op basis van de titel, één label toegekend. In een beperkt aantal gevallen (minder dan tien) zijn twee labels aan één artikel toegekend. Vervolgens zijn de artikelen met labels die met elkaar verwant zijn, gegroepeerd tot grotere clusters. Zo zijn artikelen over competenties, leren en employability bijvoorbeeld samengevoegd tot één cluster. In tabel 1 geven wij een overzicht van de resultaten.

Tabel I De 15 meest voorkomende thema's in 10 jaar Gedrag \& Organisatie (1999-2008, jaargang I2-2I; totaal circa 280 artikelen)

\begin{tabular}{|c|c|c|}
\hline $\begin{array}{l}\text { Rang- } \\
\text { nummer }\end{array}$ & Thema & $\begin{array}{r}\text { Aantal } \\
\text { artikelen }\end{array}$ \\
\hline 1 & $\begin{array}{l}\text { Leren/leervermogen/lerende organisatie (16 artikelen) } \\
\text { Employability/inzetbaarheid (II) } \\
\text { Competenties ( } 9 \text { artikelen) } \\
\text { Loopbaan ( } 7 \text { artikelen) }\end{array}$ & 43 \\
\hline 2 & $\begin{array}{l}\text { Psychische vermoeidheid/gezondheid/welbevinden/burn-out ( } 13 \text { artikelen) } \\
\text { Job Demands-Job Control-Job Resources(-model)/DISC-model (II artikelen) } \\
\text { Stressoren/stress/stressmanagement }(9 \text { artikelen) } \\
\text { Emotionele belasting/emoties op het werk ( } 6 \text { artikelen) }\end{array}$ & 39 \\
\hline 3 & $\begin{array}{l}\text { Psychologisch contract (I0 artikelen) } \\
\text { Rechtvaardigheid ( } 12 \text { artikelen) } \\
\text { Baanonzekerheid ( } 7 \text { artikelen) } \\
\text { Beloning/salaris ( } 3 \text { artikelen) }\end{array}$ & 32 \\
\hline 4 & Leiderschap & 18 \\
\hline 5 & $\begin{array}{l}\text { Prestatie/presteren/productiviteit (II artikelen) } \\
\text { Innovatief werkgedrag ( } 6 \text { artikelen) }\end{array}$ & 17 \\
\hline 6 & $\begin{array}{l}\text { Arbeid en zorg/werk-privé/werk-thuis ( } 7 \text { artikelen) } \\
\text { Diversiteit/allochtonen/etnische minderheden ( } 6 \text { artikelen) } \\
\text { Oudere werknemers ( } 3 \text { artikelen) }\end{array}$ & 16 \\
\hline 7 & $\begin{array}{l}\text { Beoordeling/assessment/werving/selectie ( } 10 \text { artikelen) } \\
\text { Sollicitatie/sollicitanten/werk zoeken (5 artikelen) }\end{array}$ & 15 \\
\hline 8 & $\begin{array}{l}\text { Pesten op het werk ( } 9 \text { artikelen) } \\
\text { Conflicten op het werk ( } 6 \text { artikelen) }\end{array}$ & 15 \\
\hline 9 & $\begin{array}{l}\text { Ziekteverzuim/-beleid ( } 5 \text { artikelen) } \\
\text { Personeelsverloop/vertrek/mobiliteit ( } 4 \text { artikelen) } \\
\text { Arbeidsre-integratie }(2 \text { artikelen }) \\
\text { Werkloosheid/pensioen ( } 2 \text { artikelen) }\end{array}$ & 13 \\
\hline 10 & $\begin{array}{l}\text { Binding/betrokkenheid/identificatie met organisatie ( } 7 \text { artikelen) } \\
\text { Arbeidstevredenheid ( } 3 \text { artikelen) }\end{array}$ & 10 \\
\hline 11 & Samenwerken/teams/solidair gedrag & 10 \\
\hline 12 & Cultuur/crossnationaal & 8 \\
\hline 13 & Automatisering/ICT & 5 \\
\hline 14 & Organisatieverandering(sprocessen) & \\
\hline 15 & Functionele flexibiliteit/flexibele werkomgeving & 3 \\
\hline
\end{tabular}

Een vergelijking van de thema's die de laatste tien jaar van Gedrag \& Organisatie prevaleren, met de thema's uit het handboek van Drenth et al. (1984) levert de volgende meer algemene conclusies op: het opkomen of verder uitbouwen van de belangstelling voor (1) competenties, leren en employability, (2) rechtvaardige arbeidsverhoudingen en psychologische contracten, (3) vermoeidheid, burn-out en stress en de werkoorzaken daarvan, (4) prestaties, productiviteit en innovatief gedrag van individuen en organi- 
saties, (5) pesten, agressie en intimidatie op de werkplek, en de mogelijk daarmee samenhangende conflicten, en het verdwijnen van thema's als medezeggenschap, werkoverleg en bedrijfsdemocratisering. Daarvoor in de plaats gekomen zijn als het ware de thema's psychologisch contract en rechtvaardigheid in arbeidsrelaties. Ook is de veel minder grote aandacht voor organisatieverandering, organisatieontwikkeling en werkstructurering opvallend.

Opvallend in tabel 1 is verder dat het wat traditionele thema van beoordeling, werving, selectie en sollicitatie met slechts vijftien artikelen in de middenmoot staat.

Een deel van deze conclusies wordt ook getrokken door De Lange (2007) naar aanleiding van een door hem uitgevoerde inhoudsanalyse van tien jaar (1998-2007) Tijdschrift voor Human Resources Management. Het traditionele onderwerp personeelsbeleid staat daar uiteraard op nummer 1, maar ontwikkeling van medewerkers (nummer 2), competentiemanagement (nummer 6), contractuele relaties/arbeidsrelaties (nummer 4), prestaties (nummer 5) en de oudere werknemer (nummer 9) scoren daar, net als in Gedrag \& Organisatie, hoog. Thema's als burn-out en stress en pesten en conflicten treft men in het Tijdschrift voor HRM niet of weinig aan. Volgens de auteur zelf springen drie ontwikkelingen hierbij sterk in het oog: het accent op prestaties, de ontwikkeling van medewerkers en de verregaande individualisering, bijvoorbeeld in contractuele relaties en arbeidsvoorwaarden. Dit komt overeen met onze analyse van de bijdragen in Gedrag \& Organisatie.

Een inhoudsanalyse van het Tijdschrift voor Arbeidsvraagstukken (TvA) laat zien dat A\&O-psychologen in TvA - weliswaar in beperkte mate - rond drie thema's hebben gepubliceerd, namelijk: arbeidsverhoudingen (vakbondslidmaatschap, vakbondsacties, medezeggenschap, de relatie werkgever-werknemer, het psychologisch contract), arbeidsmarktonderzoek (baan- en arbeidsonzekerheid) en arbeidsoriëntaties en arbeidswaarden.

Hoewel TvA als beleid heeft om aandacht te besteden aan thema's die ook in de psychologie in de belangstelling staan, zoals arbeid en zorg, ICT en arbeid, en kwaliteit van de arbeid (werkdruk, stress), werden de artikelen in TvA over deze thema's vooral door sociologen geschreven.

\section{Enkele thema's nader belicht}

Op basis van de meest voorkomende thema's in Gedrag \& Organisatie van de afgelopen tien jaar (zie tabel 1) gaan we hier dieper in op de ontwikkelingen in de drie meest behandelde thema's.

\section{Competenties, leren en employability}

In gerenommeerde Engelstalige handboeken over de $\mathrm{A} \& \mathrm{O}-$ psychologie (Anderson et al., 2001; Borman et al., 2003; Spector, 2008) zoekt men tevergeefs naar substantiële teksten over het thema employability. Maar bij het uitvoeren van een zoekopdracht met het woord 'employability' in de titel worden toch gauw driehonderd of meer artikelen gevonden. Vele daarvan gaan over de werkmogelijkheden (inzetbaarheid) van speciale groepen als zieken en gehandicapten, werklozen, buitenlandse studenten, ouderen, allochtonen of ex-gevangenen. Pas het laatste decennium is de term employ- 
ability in zwang gekomen in publicaties die betrekking hebben op de gemiddelde werkende. Nederlandse auteurs spelen daarin een belangrijke rol.

Met name door snelle technologische ontwikkelingen en internationale concurrentiedruk zijn de competenties van medewerkers en dus blijvend leren tot een cruciale factor voor de concurrentiepositie van organisaties geworden (Van Dam et al., 2006).

Inmiddels is door A\&O-psychologen aandacht besteed aan het bedrijfsbeleid ten aanzien van inzetbaarheid (De Vries et al., 2001) en aan de determinanten ervan (Nauta et al., 2009). De maatregelen die bedrijven nemen om de inzetbaarheid van hun werknemers te vergroten, zijn vooral scholing en training, taakverruiming, taakverrijking, taakroulatie en flexibilisering van taken, functies en werktijden (De Vries et al., 2001). Inzetbaarheid kan worden bevorderd door het creëren van een inzetbaarheidscultuur in bedrijven (Nauta et al., 2009). Dit houdt in dat de organisatie mensen aanmoedigt om te leren, hun vaardigheden te ontwikkelen, te experimenteren, en van tijd tot tijd van taak te veranderen. Van Dam et al. (2006) noemen bovendien nog werksituatiekenmerken die tot leren, leergedrag en inzetbaarheid aanzetten, zoals autonoom, uitdagend, complex en verantwoordelijk werk.

Vanwege de ontgroenings- en vergrijzingsproblematiek en de wens van de overheid om oudere werknemers voor de arbeidsmarkt te behouden, speelt op het vlak van leren, leergedrag en inzetbaarheid van werknemers het leeftijdsperspectief een belangrijke rol. Volgens Van Dam et al. (2006) zou aangetoond zijn dat oudere werknemers minder actief zijn dan jongeren waar het gaat om zowel trainingen op het werk als door de werkgever betaald leren buiten het bedrijf.

Dit resultaat hoeft niet te duiden op onwil of desinteresse van oudere werknemers. Het kan zijn dat de adequate opleidingen hun niet worden aangeboden. Voor ouderen kan ook gelden dat hun baan zelf al veel leren en het aanwenden van creativiteit inhoudt, accumulerend in ervaring, zodat aparte opleidingen en cursussen minder urgent zijn. Dat er aanleiding is om dit te denken, toont figuur 1.

Figuur I Mate van creatief, lerend en gevarieerd werk, naar leeftijd en geslacht (\% vaak en altijd, NEA 2007 en 2008 samen)

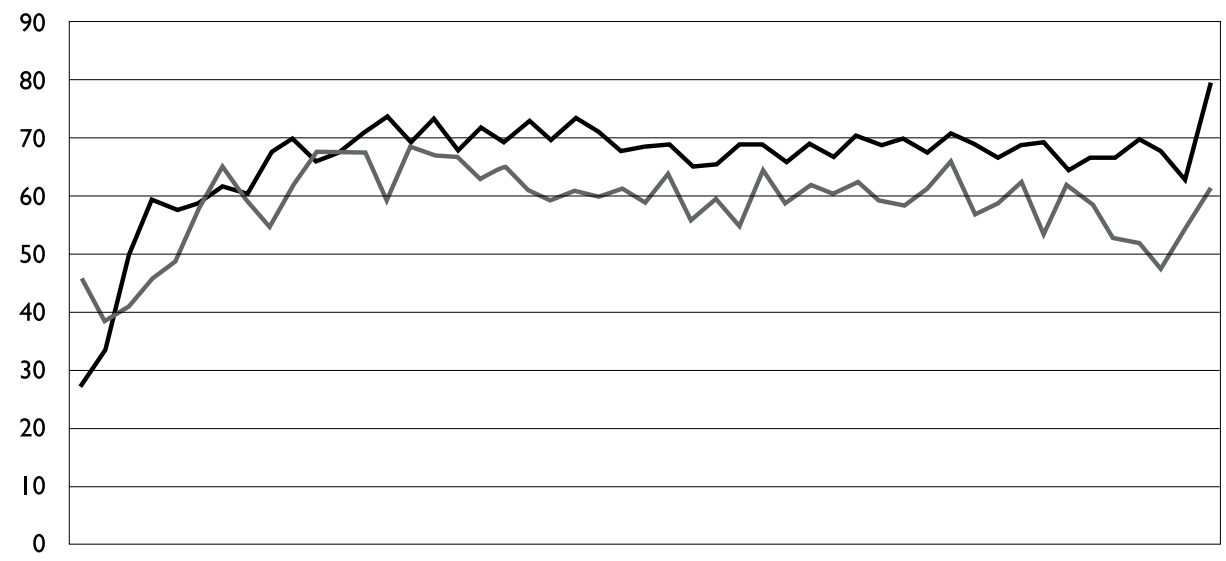

$\begin{array}{lllllllllllllllllllllllll}16 & 18 & 20 & 22 & 24 & 26 & 28 & 30 & 32 & 34 & 36 & 38 & 40 & 42 & 44 & 46 & 48 & 50 & 52 & 54 & 56 & 58 & 60 & 62 & 64\end{array}$ - vrouwen $(n=20.083) \quad$ mannen $(n=23.734)$

Deze figuur is gebaseerd op het grootste jaarlijkse landelijk onderzoek naar arbeid in Nederland, de Nationale Enquête Arbeidsomstandigheden (NEA), die TNO en CBS 
onder een nettosteekproef van circa 24.000 werknemers uitvoeren (Koppes et al., 2009).

In de figuur valt namelijk te zien dat creatief, lerend en gevarieerd werk eerst toeneemt met de leeftijd, zijn top bereikt rond het dertigste levensjaar, en daarna op een relatief gelijk niveau blijft. Deze percentages uit grootschalig representatief en landelijk onderzoek kleuren de discussie over het leren en de inzetbaarheid van oudere werknemers wat minder zwart-wit dan die soms lijkt te zijn. In het algemeen kan de conclusie zijn dat meer landelijk representatieve feiten nodig zijn over leergedrag, leerwensen en leermogelijkheden in het werk dan thans het geval is. Onderzoek naar het achterblijven van functies, beroepen en/of bedrijfssectoren op het punt van leren en leren-in-hetwerk lijkt eveneens wenselijk. Dit soort studies kunnen ook de beleidsrelevantie van het thema verstevigen.

Van Dam et al. (2006) merken op dat van een gedegen conceptualisatie en operationalisatie van het verschijnsel employability nog geen sprake is. Het kan bijvoorbeeld gaan om de vaardigheden die nodig zijn voor een baan, het vermogen om werk te kunnen vinden of te houden, de activiteiten waarmee individuen hun inzetbaarheid kunnen vergroten, alsook de effecten van inzetbaarheid op de arbeidsmarktpositie. Er zijn dus duidelijk nog theoretische stappen te zetten op dit terrein. Daarnaast is vanuit economisch en sociologisch perspectief een interessante en nog op te pakken vraag welke rol leren, inzetbaarheid en inzetbaarheidbeleid van bedrijven spelen in arbeidsmarktvraagstukken, met name in de arbeidsparticipatie van de beroepsbevolking.

\section{Rechtvaardige arbeidsverhoudingen, het psychologisch contract en baanonzekerheid}

Schalk et al. (2002) stellen dat de relatie tussen werknemers en hun organisaties het laatste decennium in het teken staat van flexibele arbeidscontracten, van minder collectivisering en meer individualisering van arbeidsrelaties, en - mogelijk door flexibilisering en individualisering - van een lossere band en meer baanonzekerheid. Volgens deze en andere auteurs zou overgegaan zijn van oude psychologische contracten - met als kenmerken stabiliteit, voorspelbaarheid, standaardwerkpatronen, loyaliteit en zekerheid - naar nieuwe psychologische contracten waarin verandering, onzekerheid, flexibiliteit, het leveren van prestaties en levenslang leren centraal staan.

In de flexibeler en onzekerder wordende organisatie is daarom versterking van de binding en de betrokkenheid van werknemers bij hun bedrijf van groot belang. De gedachte is dat dit plaats kan vinden door een versterking van het 'psychologisch contract' van de werknemers met hun organisatie. Anderen (bijvoorbeeld Ybema, 2007) menen dat een rechtvaardiger behandeling en beloning een te hoog niveau van onzekerheid, werkontevredenheid en burn-out kunnen voorkomen. Het moge duidelijk zijn dat de flexibilisering van contracten, functies en werktijden en veronderstelde individualisering het onderzoek naar baanonzekerheid door $\mathrm{A} \& \mathrm{O}$-psychologen gestimuleerd hebben. Met name aan de Universiteit van Leuven heeft men daar een speerpunt van onderzoek van gemaakt (zie bijvoorbeeld De Witte \& Van Hecke, 2003).

Freese et al. (2008) hebben een vragenlijst ontwikkeld om aspecten van het psychologisch contract te meten. Het gaat daarbij om organisatieverplichtingen als goede inhoud van het werk, loopbaanontwikkeling, sociale sfeer, beloningen, en om werknemersverplichtingen als samenwerken, eerlijkheid, service verlenen, het hoog houden van het imago van de organisatie, positief meedenken met de organisatie, enzovoort. De auteurs 
konden empirisch vaststellen dat organisatie- en werknemerverplichtingen voorspellende waarde hebben voor de betrokkenheid bij de organisatie en de verloopgeneigdheid.

Echter, cijfers uit de Nationale Enquête Arbeidsomstandigheden (NEA) laten zien dat het met de flexibilisering van contractvormen nogal meevalt. Over de periode 20032008 is het percentage werknemers met vast dienstverband (of uitzicht daarop) namelijk zo rond de $90-92 \%$ gebleven. Werknemers met een tijdelijk contract, een uitzend- of een oproepcontract zijn dus in omvang zo'n 8-10\% van alle werknemers gebleven. Een gelijksoortige conclusie werd ook reeds getrokken door Huiskamp en Schalk (2002). Deze conclusie doet niets af aan de relevantie van het begrip psychologisch contract. Het oude type psychologisch contract, waarin loyaliteit en werkzekerheid centraal staan, lijkt echter (nog) niet vervangen door een nieuw type contract, waarin flexibiliteit, een leven lang leren en brede inzetbaarheid centraal staan.

Zoals al eerder opgemerkt, zijn in de 25 jaar die we hier beschouwen, arbeidsrelationele thema's als medezeggenschap, werkoverleg en bedrijfsdemocratisering uit de belangstelling van de $\mathrm{A} \& \mathrm{O}-$ psychologie verdwenen en is er op het gebied van de arbeidsverhoudingen meer accent gelegd op de thema's psychologisch contract, rechtvaardigheid en baanonzekerheid. Of en in hoeverre dit nu een vooruitgang is, is een vraag.

Het gebied van (psychologische) contracten en arbeidsverhoudingen is bij uitstek een terrein waarop psychologen, economen en sociologen onderzoeksmatig actief zijn (geweest). In dit tijdschrift is de laatste jaren bijvoorbeeld door Huiskamp et al. (2005) aandacht besteed aan goed werkgeverschap. Onderzoek naar inhoud en effecten van collectieve arbeidsovereenkomsten heeft met name in de laatste decennia van de vorige eeuw veel aandacht gehad. Een vraag die in dit verband gesteld kan worden, is wat de relatie is tussen bepaalde vormen van psychologische contracten, rechtvaardige arbeidsrelaties, cao-inhouden, vormen van medezeggenschap en vakbondsactiviteiten. Dit zou een interessant onderwerp voor samenwerking tussen psychologen en sociologen kunnen zijn.

\section{Stress, vermoeidheid en burn-out}

Stress is een onderwerp waar een groot aantal wetenschappelijke disciplines zich mee bezighoudt. In de psychologie komt het in een verwarrend aantal gedaantes voor. Stress bestaat als stimulus, als reactie op een stimulus en als een verstoorde relatie tussen het individu en zijn omgeving.

Stress in organisaties is een thema dat ook al in de jaren tachtig in het Handboek arbeid \& organisatie psychologie werd behandeld. In die tijd stond de Person-Environment Fittheorie (French et al., 1982) centraal. In deze theorie leidt incongruentie tussen omgeving en individu tot stress. Meer in concreto: overbelasting door het werk, bijvoorbeeld door tijdsdruk, kan leiden tot fysiologische, psychologische en/of tot gedragsmatige stressreacties, ook wel strains genaamd, die vervolgens tot gezondheidsklachten, ziekten, ziekteverzuim en burn-out kunnen leiden. Aan de kant van de persoon spelen persoonlijkheidskenmerken (bijvoorbeeld Type A-persoonlijkheid en copinggedrag) en sociale steun van de omgeving een mitigerende rol.

In de laatste twee decennia is op het gebied van werkstress een enorme aandacht ontstaan voor het zogenoemde Job Demands-Job Control-model van Karasek (1979). In dit model werd de combinatie 'high demands-low control' als meest nadelig voor de gezondheid van de werkende bevolking gehouden. In grote lijnen leverde empirisch 
onderzoek ondersteuning op voor dit model (Sonnentag \& Frese, 2003). Toch lijkt de belangstelling en aandacht voor dit model de laatste jaren tanende te zijn, mede door de opkomst van een aantal alternatieve werkstresstheorieën.

Een daarvan is het zogenoemde Vitamine Model (Warr, 1987), waarin de auteur claimde dat de relatie tussen werkkenmerken en individuele 'outcomes' kromlijnig zou zijn. Dus een bepaalde mate van taakautonomie, taakvariatie, taakeisen en sociale steun zou goed zijn voor de werknemer, maar een heel hoog niveau van deze kenmerken zou stress tot gevolg hebben. De empirische studies naar het Vitamine Model zijn nog beperkt in aantal en de resultaten gemengd (Sonnentag \& Frese, 2003).

Door Siegrist (1996) is het Effort-Reward Imbalance Model voorgesteld als oorzaak van stressreacties. Dit model is een variant van het Person-Environment Fit-model. Het gaat hier om de kosten (vereiste inspanningen) en baten (beloning, achting, status) van het individu in de werksituatie. Een aantal empirische onderzoeken heeft de waarde van dit model onderlijnd.

In Nederland zijn nog twee andere werkstressmodellen gepropageerd. Het gaat hier om het Job Demands-Resource-model (JD-R-model) en het Demand-Induced Strain Compensation Model (DISC-model). In het boek van Schaufeli \& Bakker (2007) over de psychologie van arbeid en gezondheid is aan deze stressmodellen een hoofdstuk gewijd (De Jonge et al., 2007).

Een nog te vermelden verworvenheid van de laatste decennia zijn de vele interventiestudies rond stress in het werk die inmiddels uitgevoerd zijn. Kompier (2007) concludeerde dat er bij werkstress zowel werknemergerichte maatregelen als werk- en organisatiegerichte maatregelen in zwang zijn. Bij de individugerichte aanpak gaat het bijvoorbeeld om competentietraining, 'relaxation', antirook- en fitheidstrainingen (Sonnentag \& Frese, 2003). Bij de werk- en organisatiegerichte aanpak gaat het om beperking van de werkgerelateerde stressoren, zorgen voor meer participatie in beslissingen, inbouwen van rustperiodes, enzovoort. Op grond van internationale evaluaties concludeert Kompier (2007), dat stressmanagement in de praktijk nogal veel neerkomt op het verzachten van de stresseffecten en weinig op de bestrijding van risicofactoren in het werk zelf. Deze praktijk dient meer de belangen van het management dan die van de werknemers. Op basis van gevalsstudies benoemt Kompier (2007) een vijftal succesfactoren voor het welslagen van interventies: een stapsgewijze en systematische aanpak, een adequate diagnose, theoretisch gefundeerde maatregelen, een participatieve aanpak en steun van het (top)management.

Burn-out wordt gezien als een stressreactie die op wat langere termijn ontstaat. Burnout wordt gekenmerkt door (a) emotionele uitputting, het gevoel helemaal 'op' of 'leeg' te zijn als gevolg van het werk, (b) mentale distantie, een cynische, afstandelijke en weinig betrokken houding ten opzichte van het werk dat men verricht, en (c) competentieverlies.

Om burn-out in de werksituatie te meten is door Schaufeli \& Van Dierendonck (2000) de Utrechtse Burnout Schaal (UBOS) vervaardigd. Met de UBOS kunnen 'opgebrande' van 'niet-opgebrande' werknemers worden onderscheiden. Mogelijk mede door het beschikbaar zijn van de UBOS en het feit dat in Nederland psychische klachten en overspannenheid breed geaccepteerde verschijnselen zijn, krijgt het thema burn-out door het werk in Nederland relatief veel aandacht. Het Centraal Bureau voor de Statistiek heeft de vijf vragen over emotionele uitputting, de belangrijkste burn-outindicator, in de POLS-enquête (Permanent Onderzoek Leefsituatie) opgenomen en kan dus trends 
en risicogroepen identificeren. Ook in de NEA is het UBOS-deel over emotionele uitputting opgenomen.

Uit de NEA-cijfers 2007-2008 kunnen we concluderen dat emotionele uitputting gemiddeld iets hoger is bij mannen dan bij vrouwen (zie figuur 2). Het lijkt er verder op dat vrouwen in de leeftijdsperiode 25-35 jaar - mogelijk door de dubbele belasting van werk en gezin - meer met emotionele uitputting te maken hebben dan hun mannelijke leeftijdsgenoten.

Opvallend is ten slotte, dat het thema stress, vermoeidheid en burn-out weinig door arbeidssociologen en -economen is omarmd. Het is goed denkbaar om in de sociologie bijvoorbeeld organisatiekenmerken te koppelen aan stress en burn-out. Ook lijken de kosten en baten van stress en burn-out voor economen een relevant arbeidsterrein te kunnen zijn. Het lijkt er overigens eerder op dat dit thema thans wordt opgepakt door bedrijfskundigen.

Figuur 2 Burn-out door het werk, naar leeftijd en geslacht (\% maandelijks of frequenter, NEA 2007 en 2008 samen)

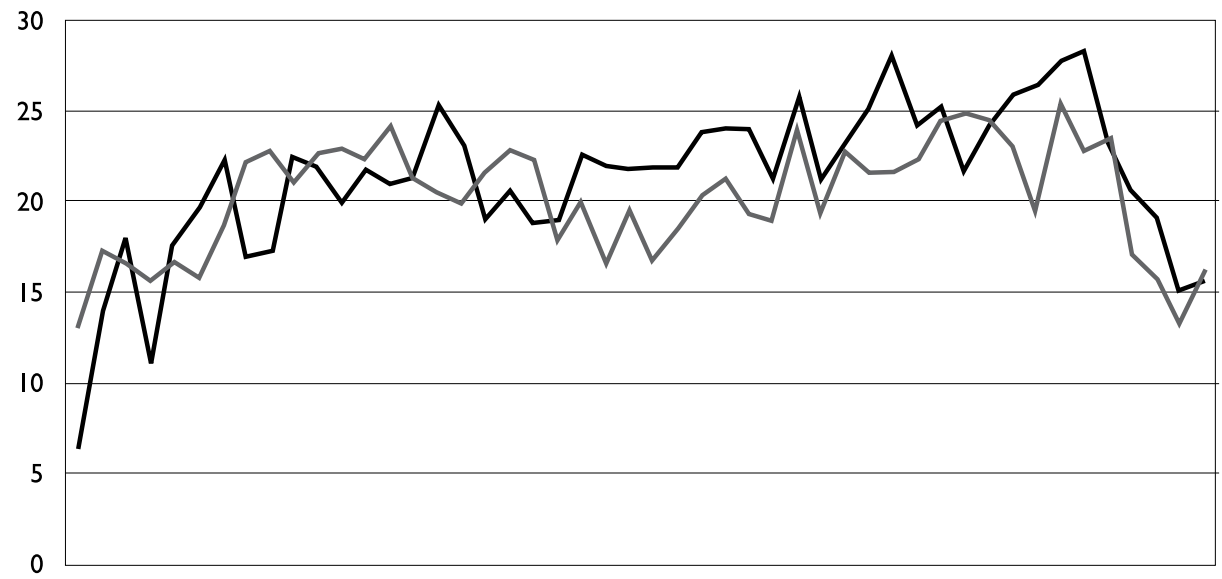

$\begin{array}{llllllllllllllllllllllll}16 & 18 & 20 & 22 & 24 & 26 & 28 & 30 & 32 & 34 & 36 & 38 & 40 & 42 & 44 & 46 & 48 & 50 & 52 & 54 & 56 & 58 & 60 & 62\end{array}$

vrouwen $(n=20.457)$ mannen $(n=24.155)$

\section{Conclusies en een toekomstagenda}

Op basis van onze analyse van reviewartikelen, historische beschouwingen en trendanalyses van 25 jaar A\&O-psychologie kunnen we concluderen dat er theoretisch en methodisch velerlei, elkaar deels onderling versterkende ontwikkelingen hebben plaatsgevonden.

Inhoudelijk bleek dat in de internationale literatuur over een aantal thema's in groeiende frequentie gepubliceerd werd: prestatiebeoordeling en -feedback, besluitvorming, organisatiecultuur, teams en werkgroepen, stress en burn-out, en ten slotte arbeid en de thuissituatie. De aandacht hiervoor liep niet altijd parallel aan de maatschappelijke ontwikkelingen.

In het Nederlandse tijdschrift Gedrag \& Organisatie waren drie onderwerpen in de afgelopen tien jaar het meest populair: (1) competenties, leren en employability, (2) rechtvaardige arbeidsverhoudingen, het psychologisch contract en baanonzekerheid, 
en (3) stress, vermoeidheid en burn-out. Verder was in Gedrag \& Organisatie de sterk toegenomen aandacht voor prestaties en productiviteit, en innovatief gedrag opvallend. Ook het opkomen van het thema pesten, agressie en intimidatie op de werkplek - een duidelijk inspelen op een maatschappelijk vraagstuk - valt te vermelden. Deze ontwikkelingen lopen deels parallel met in het oog springende trends die in het Tijdschrift voor HRM gesignaleerd werden.

Ten slotte werd er in Nederland een pleidooi gehouden voor een positievere kijk op werk, met daarbij aandacht voor trots, geluk en bevlogenheid. Deze oproep vond in Nederland zeker weerklank, in het buitenland minder. Op een aantal terreinen spelen Nederlandse en Vlaamse A\&O-psychologen internationaal een vooraanstaande rol. Dit geldt bijvoorbeeld voor thema's als werk en gezondheid, employability en baanonzekerheid.

Anderzijds is voor sommige thema's in Nederland de aandacht sterk verminderd. Het gaat hier bijvoorbeeld om medezeggenschap, werkoverleg en bedrijfsdemocratisering. Daarvoor in de plaats zijn de thema's psychologisch contract en rechtvaardigheid in arbeidsrelaties gekomen. Ook lijkt er in de A\&O-psychologie veel minder grote aandacht voor organisatieverandering en -ontwikkeling en werkstructurering.

Ook op het gebied van de methodologie zijn er nieuwe ontwikkelingen geweest. Door vele auteurs zijn meta-analyses en nieuwe onderzoeksmethoden en -technieken positief beoordeeld omdat zij perspectief bieden op nieuwe inzichten. Van de andere kant wordt er echter ook gewezen op lacunes in het wetenschappelijk onderzoek. Met name de kloof tussen wetenschap en praktijk is en blijft een belangrijk aandachtspunt, omdat de trends in wetenschappelijke publicaties maar losjes zijn gerelateerd aan maatschappelijke veranderingen. De analyse van de Nederlandse situatie wijkt hier enigszins positief vanaf, want Nederlandse psychologen lijken wel meer aan te sluiten bij maatschappelijke topics. Mogelijk heeft dit te maken met de vruchtbare juridische, politieke, maatschappelijke en institutionele bodem waarop psychologisch onderzoek kan gedijen.

De gepresenteerde lacunes in het A\&O-psychologisch onderzoek hebben dus ten dele te maken met het gebrek aan aansluiting bij maatschappelijke veranderingen. Cascio heeft twee keer een onderzoeksagenda voor de A\&O-psychologie geformuleerd op basis van de veranderende wereld van arbeid (Cascio, 1995; Cascio \& Aguinis, 2008). In de meest recente versie probeerden Cascio \& Aguinis (2008) een onderzoeksagenda voor de toekomst af te leiden uit de maatschappelijke ontwikkelingen ('human capital trends'), die volgens hen de 45 jaar die ze analyseerden, karakteriseerden. Enkele 'human capital trends' die zij benoemen, zijn vrouwenemancipatie, streven naar gelijke beloning, participatief management, nieuwe technologieën, groei van de dienstensector, telewerken, virtuele teams, inkrimping enzovoort. Tegen deze achtergrond noemen Cascio en Aguinis (2008) een dertiental vraagstukken waarop - in hun visie - meer onderzoek gewenst is om de kloof met de praktijk te dichten. Verkort weergegeven zijn dit:

1 Hoe zijn inspirerende en motiverende leidinggevenden te ontwikkelen?

2 Wat zijn de effecten van flexibele beloningen en uitkeringen op de motivatie en prestaties?

3 Hoe is de vertrouwenskloof inzake de beloning van hogere leidinggevenden te dichten?

4 Hoe kunnen flexibel werk en flexibele werktijden bijdragen aan de werk-thuisrelatie? 
5 Hoe is de kennis van afzwaaiende ouderen te behouden en hoe is hun vertrek te beperken?

6 Hoe is de diepgewortelde houding ten opzichte van oudere werknemers te veranderen?

7 Wat zijn de gevolgen van arbeidsintensivering voor de gezondheid van werkenden?

8 Hoe is het belang van mensen en systemen voor prestaties van organisaties te ontrafelen?

9 Wat is de beste aanpak voor de verandering van de cultuur in organisaties?

10 Hoe zijn veranderingsprocessen te leren accepteren en is innovatie te stimuleren?

11 Hoe kan de diversiteit van gedachten en oriëntaties een rol spelen in de prestaties van individuen en organisaties?

12 Wat is de effectiefste strategie om de prestatie van 'global virtual teams' te managen?

13 Onder welke condities ontstaat ethisch en onethisch gedrag in organisaties?

Ook voor Nederlandse A\&O-psychologen lijken dit actuele en relevante vraagstukken, waarop onderzoeksinspanningen gewenst zijn. Op basis van onze eigen analyses zouden we daar nog een aantal onderzoekswensen aan toe willen voegen.

Ten eerste zijn - om de beleidsrelevantie te onderlijnen - meer landelijk representatieve cijfers gewenst over thema's waar A\&O-psychologen zich mee bezighouden. Dit geldt bijvoorbeeld voor leerwensen, leergedrag en leermogelijkheden, maar ook voor zaken als onrechtvaardige arbeidsverhoudingen, pesten op het werk, stress, burn-out enzovoort. Onderzoek naar het achterblijven van functies, beroepen en/of bedrijfssectoren op deze aspecten komt men weinig tegen in de A\&O-psychologie. Dit soort studies lijken psychologen over te laten aan CBS of SCP en andere instanties.

Ten tweede en mogelijk met het vorige punt samenhangend, lijkt de in het buitenland gesignaleerde 'grotebedrijvenbias' - die consequenties kan hebben voor de generalisatie van de onderzoeksresultaten - ook wel voor de Nederlandse A\&O-psychologie op te gaan. Met name de gang van zaken bij kleine bedrijven en bij zelfstandigen blijft ook in Nederland relatief vaak onzichtbaar.

Ten derde leent een aantal thema's uit de A\&O-psychologie zich goed voor meer interdisciplinaire samenwerking met sociologen, economen en bedrijfskundigen. De huidige universitaire constellatie stimuleert dat niet. We denken hier bijvoorbeeld aan interdisciplinaire samenwerking rond psychologische contracten, collectieve arbeidsovereenkomsten (cao's) en formele personeelsvertegenwoordiging (ondernemingsraden, vakbonden enzovoort).

Ten vierde is een beleidsvraag welke rol leren, employability en inzetbaarheidbeleid van bedrijven spelen in de arbeidsparticipatie van de beroepsbevolking. De relatie tussen beide concepten wordt aangenomen, maar empirisch onderzoek verdient verdere uitbouw. Hier is mogelijk interdisciplinaire samenwerking tussen psychologen, sociologen en economen gewenst.

Ten slotte is het zeer denkbaar dat de arbeidssociologie, economie en/of bedrijfskunde zich verder verdiepen in de invloed van organisatiekenmerken op stress en burn-out, en de kosten en baten van stress en burn-out.

\section{Literatuur}

Agarwal, R. \& Hoetker, G. (2007). A Faustian bargain? The growth of management and its relationship with related disciplines. Academy of Management Journal, 50, 1304-1322. 
Anderson, N., Ones, D.S., Sinangil, H.K. \& Viswesvaran, C. (Eds.) (2001). Handbook of industrial, work and organizational psychology (two volumes). London: Sage.

Borman, W.C., Klimoski, R.J. \& Ilgen, D.R. (2003). Stability and change in industrial and organizational psychology. In W.C. Borman, D.R. Ilgen \& R.J. Klimoski (Eds.), Handbook of psychology, volume 12: Industrial and organizational psychology (chapter 1, pp. 1-17). Hoboken, NJ: John Wiley \& Sons.

Cascio, W.F. (1995). Whither industrial and organizational psychology in a changing world of work? American Psychologist, 50, 928-939.

Cascio, W.F. \& Aguinis, H. (2008). Research in industrial and organizational psychology from 1963 to 2007: Changes, choices, and trends. Journal of Applied Psychology, 93, 1062-1081.

Cox, T. \& Tisserand, M. (2006). Work \& Stress comes of age: Twenty years of occupational health psychology. Work \& Stress, 20, 1-5.

Dam, K. van, Heijden, B.I.J.M. van der \& Schyns, B. (2006). Employability en individuele ontwikkeling op het werk. Gedrag \& Organisatie, 19, 53-68.

De Witte, H. \& Van Hecke, M. (2003). Schending van het psychologisch contract, baanonzekerheid en arbeidstevredenheid, Gedrag \& Organisatie, 15, 484-501.

Drenth, P.J.D., Thierry, H., Willems, P.J. \& Wolff, Ch.J. de (red.) (1984). Handboek arbeid \& organisatie psychologie (twee delen). Deventer: Van Loghum Slaterus.

Dunnette, M.D. (Ed.) (1976). Handbook of industrial and organizational psychology. Chicago: Rand McNally College Publishing Company.

Dunnette, M.D. (1998). Emerging trends and vexing issues in industrial and organizational psychology. Applied Psychology: An International Review, 47, 129-153.

Erez, M. (1994). Towards a model of cross-cultural industrial and organizational psychology. In H.C. Triandis, M.D. Dunnette \& L. Hough (Eds.), Handbook of industrial and organizational psychology, Vol. IV, Theory in industrial and organizational psychology (chapter 11, pp. 589-607). Palo Alto, CA: Consulting Psychologist Press.

Freese, Ch., Schalk, R. \& Croon, M. (2008). De Tilburgse Psychologisch Contract vragenlijst. Gedrag \& Organisatie, 21, 278-294.

French, J.R.P. Jr., Caplan, R.D. \& Harrison, R.V. (1982). The mechanisms of job stress and strain. Chichester: Wiley.

Huiskamp, R. \& Schalk, R. (2002). Psychologische contracten in arbeidsrelaties: De stand van zaken in Nederland. Gedrag \& Organisatie, 15, 370-385.

Huiskamp, R., Dalen, E.J. van, Gründemann, R. \& Jongkind, R. (2005). Goed werkgeverschap en goed werknemerschap: Een bijzondere arbeidsrelatie. Tijdschrift voor Arbeidsvraagstukken, 21, 211-225.

Johns, G. (2006). The essential impact of context on organizational behavior. Academy of Management Review, 31, 396-408.

Jonge, J. de, Blanc, P. le \& Schaufeli, W. (2007). Psychosociale werkstressmodellen. In W. Schaufeli \& A. Bakker (red.), De psychologie van arbeid en gezondheid (2e herz. druk) (hoofdstuk 2, pp. 25-49). Houten: Bohn Stafleu Van Loghum.

Karasek, R. (1979). Job demands, job decision latitude, and mental strain: Implications for job design. Administrative Science Quarterly, 24, 285-306.

Kompier, M. (2007). Werk- en organisatiegerichte interventies. In W. Schaufeli \& A. Bakker (red.), De psychologie van arbeid en gezondheid (2e herz. druk) (hoofdstuk 9, pp. 193-213). Houten: Bohn Stafleu Van Loghum.

Koppes, L., Vroome, E. de, Mol, M., Janssen, B. \& Bossche, S. van den (2009). Nationale Enquête Arbeidsomstandigheden 2008. Hoofddorp: TNO Kwaliteit van Leven/divisie Arbeid.

Lange, W. de (2007). Tien jaar Tijdschrift voor HRM. Tijdschrift voor HRM, 10, 51-52.

Nauta, A., Vianen, A. van, Heijden, B. van der, Dam, K. van \& Willemsen, M. (2009). Understanding the factors that promote employability orientation: The impact of employability culture, career satisfaction, and role breadth self-efficacy. Journal of Occupational and Organizational Psychology, 82, 233-251.

Patterson, F. (2001). Developments in work psychology: Emerging issues and future trends. Journal of Occupational and Organizational Psychology, 74, 381-390.

Porter, L.W. (2008). Organizational psychology: A look backward, outward, and forward. Journal of Organizational Behavior, 29, 519-526.

Sanders, K. (2006). Arbeid \& organisatie psychologie en human resources management: It takes two to tango. Tijdschrift voor HRM, 9, 33-41.

Schalk, R. (2009). Het toekomstprofiel van Gedrag \& Organisatie. Gedrag \& Organisatie, 22, $1-2$. 
Schalk, R., Hartog, D.N. den \& Velde, M. van der (2002). Psychologische contracten, binding en betrokkenheid; editiorial. Gedrag \& Organisatie, 15, 351-354.

Schaufeli, W. (2004a). De psychologie van arbeid en gezondheid: Verleden, heden en toekomst. Gedrag \& Organisatie, 17, 327-341.

Schaufeli, W. (2004b). The future of occupational health psychology. Applied Psychology: An International Review, 53, 502-517.

Schaufeli, W. \& Bakker, A. (red.) (2007). De psychologie van arbeid en gezondheid (2e herz. druk). Houten: Bohn Stafleu Van Loghum.

Schaufeli, W.B. \& Dierendonck, D. van (2000). Utrechtse Burnout Schaal (UBOS): Handleiding. Lisse: Swets \& Zeitlinger.

Siegrist, J. (1996). Adverse health effects of high effort/low reward conditions. Journal of Occupational Health Psychology, 1, 27-41.

Smulders, P.G.W. (2005, 6 juli). Ondanks manager is arbeidsvreugde groot. De Volkskrant.

Sonnentag, S. \& Frese, M. (2003). Stress in organizations. In W.C. Borman, D.R. Ilgen \& R.J. Klimoski (Eds.), Handbook of psychology, volume 12: Industrial and organizational psychology (chapter 18, pp. 453-491). Hoboken, NJ: John Wiley \& Sons.

Sparks, K., Faragher, B. \& Cooper, C.L. (2001). Well-being and occupational health in the 21st century workplace. Journal of Occupational and Organizational Psychology, 74, 489-509.

Spector, P.E. (Ed.) (2008). Industrial and organizational psychology, research and practice. New York: John Wiley \& Sons.

Tharenou, Ph. (2001). The relevance of industrial and organisational psychology to contemporary organisations: How far have we come and what needs to be done post-2000? Australian Psychologist, 36, 200-210.

Vries, S. de, Gründemann, R. \& Vuuren, T. van (2001). Employability policy in Dutch organizations. International Journal of Human Resource management, 12, 1193-1202.

Warr, P.B. (1987). Work, unemployment, and mental health. Oxford: Oxford University Press.

Ybema, J.F. (2007). De invloed van rechtvaardigheid op werkuitkomsten: Een longitudinaal perspectief. Gedrag \& Organisatie, 20, 409-426. 